\title{
The development and content validity testing of the Quick-EBP-VIK: A survey instrument measuring nurses' values, knowledge and implementation of evidence-based practice
}

\author{
Fiona Paul , Linda Connor, Margaret McCabe, Sonja Ziniel \\ Boston Children's Hospital, Boston, MA, United States
}

Received: November 4, 2015

Accepted: November 19, 2015 Online Published: January 21, 2016

DOI: $10.5430 /$ jnep.v6n5p118

URL: http://dx.doi.org/10.5430/jnep.v6n5p118

\begin{abstract}
Objective: A validated survey tool that concisely measures nurses' values, knowledge and implementation of evidence-based practice (EBP) is needed to develop needs-based curricula for continuing nurse education. Purpose: Develop a succinct measurement instrument, the Quick-EBP-VIK, assessing nurses' values, implementation and knowledge of EBP, to establish face and content validity.

Methods: In Phase I-Review of the existing literature to establish topic domains, developed and refined questions. Phase II established face validity, and Phase III content validity using EBP experts as raters.

Results and conclusions: Twenty-five questions met the clarity and relevance criteria with content validity indices of $>0.80$. Questions were critically evaluated by EBP experts from both academic and clinical settings across the country for relevance and clarity and revised when indicated. The use of EBP experts and content validity indices resulted in a final survey instrument, measuring nurses' values, knowledge and implementation of EBP.
\end{abstract}

Key Words: Evidence based practice, Instrument development, Nursing, Values, Knowledge, Implementation

\section{INTRODUCTION}

Evidence-based practice (EBP) is a problem-solving approach to clinical practice that integrates a conscientious use of best evidence combined with clinician expertise, patient preference and values. ${ }^{[1,2]}$ The term EBP began appearing in the nursing literature in the early 1990s. It was an outgrowth of research utilization in nursing and an extension of systematic reviews, which emerged in the medical literature in the 1970s. ${ }^{[3]}$ The ultimate goal of EBP in nursing is to provide the highest quality and most cost-efficient nursing care to patients. ${ }^{[4]}$ Nurses can accomplish this by implement- ing and translating evidence into clinical guidelines. The implementation of EBP has been demonstrated to produce better outcomes when compared to traditional-based care. ${ }^{[2]}$ Despite wide acceptance as a gold standard to providing safe and high quality patient care, it is estimated that only a small percentage of nurses implement EBP on a consistent basis. ${ }^{[5]}$ A lack of understanding of EBP and how evidence is integrated into practice has resulted in poor participation by nurses. ${ }^{[6]}$ Consequently, evidence-based practice education has become a critical part of academic curricula and ongoing education programs for nurses with foci on the value of EBP

*Correspondence: Fiona Paul; Email: Fiona.paul@childrens.harvard.edu; Address: Boston Children’s Hospital, Boston, MA, United States. 
for best care practices, the knowledge and understanding of the aspects of the EBP process, and the actual use of EBP in every day care practices. ${ }^{[5,7]}$

EBP has been a part of the nursing culture at our institution, a 396-bed free standing pediatric Magnet designated academic hospital, for more than ten years. Introducing a new way of practice proved challenging, as many nurses wanted to continue with their traditional ways of providing care. Over a period of time, numerous educational offerings have been put in place to build an institutional philosophy of EBP. Nevertheless, anecdotal evidence suggested that nurses across the institution varied with regard to their value, knowledge and implementation of EBP. The lack of existing factual data led to the formation of a committee to evaluate this.

The committee agreed that a short tool to evaluate the nurse's value, knowledge and implementation of EBP and measured change over time would best meet the institution's need. Some of the existing tools were estimated to take more than 15 minutes to complete and contained questions that were not relevant to our three domains. For example, the 64-item Nurses' Readiness for Evidence Based Practice survey, ${ }^{[8]}$ and the 93-item questionnaire survey described by Pravikoff, Tanner and Pierce. ${ }^{[9]}$ Other instruments were either not comprehensive enough or did not include the three topic domains of interest. For example, the belief and implementation scales by Melnyk et al. ${ }^{[5]}$ include knowledge questions, but do not dedicate a separate scale for assessing knowledge. Therefore, the aim of this study was to develop a concise and valid measure to assess nurse's value, knowledge and implementation of EBP. The current paper focuses on item creation and rigorous validity testing.

\section{Theoretical framework}

Bandura's Social Cognitive Theory (SCT) served as a framework throughout the development of the Quick-EBP-VIK survey instrument. Bandura began his work in social learning in the early 1960's. ${ }^{[10]} \mathrm{He}$ later described a direct correlation between a person's perceived self-efficacy and behavioral change. ${ }^{[10]}$ In 1986, Bandura expanded upon and renamed his theory, the social cognitive theory. There are five main concepts associated with the SCT framework; observational learning/modeling, outcome expectations, self-efficacy, goal setting and self-regulation. ${ }^{[10]}$

Self-efficacy is at the core of SCT. Self-efficacy refers to how one decides to behave, based more on belief in their own capabilities of accomplishment rather than in their actual knowledge or skills. ${ }^{[11]}$ The Quick-EBP-VIK survey instrument provides the respondent with the opportunity to self-report on value, perceived knowledge and implementa-

Published by Sciedu Press tion of EBP. The concept of self-efficacy would suggest that nurses who report a strong value of EBP, and appear confident in their level of knowledge and ability to implement EBP might be more likely to demonstrate this in practice. Once identified these nurses could function as mentors or role models for the general staff. Bandura described how some actions are learned from modeled behaviors, he refers to this concept of observational learning/modeling. ${ }^{[12]} \mathrm{Ob}$ servational learning or modeling proposes that learning is a social process which can occur through observation or by imitating others. ${ }^{[13]}$

SCT is careful to separate the concepts of knowledge and implementation. The theory assumes that people have the ability to influence their own behavior in a purposeful and goal-directed fashion. ${ }^{[14]}$ However, Bandura also states that learning can occur without an immediate change in behavior, labeling learning and the demonstration of what has been learned as distinct processes. This division of learning and behavior change guided the development of our instrument to examine knowledge and the implementation of knowledge as two separate concepts.

\section{METHODS}

This study includes three phases of tool development and validity testing. Phase I consisted of the review of existing literature to establish topic domains and the development and refinement of items. Phase II used a group of internal experts to focus on item and content refinement and Phase III used a group of external experts to further validate the tool by content validity index.

\subsection{Tool development and validity testing Phase I-Domain and item development}

The development of a new survey instrument should include a thorough review of the existing literature followed by qualitative interviews to facilitate the identification of all relevant topic domains. ${ }^{[15]}$ At the onset of this project, 2009, a review of the literature was performed to identify existing tools evaluating evidence based practice in nursing. This search revealed 29 articles which described 17 different instruments. Following careful review by the authors, it was determined none assessed all three domains of interest. An updated literature review was conducted every 6 months after the onset of this project. Two additional survey instruments were identified which again did not adequately assess the three domains of interest (see Table 1). ${ }^{[5,7,9,16-31]}$

An extensive search of the literature using EBSCO Host Medline, Cumulative Index to Nursing and Allied Health Literature (CINHAL), Educational Resources Information Center (ERIC) and Health and Psychosocial Instruments 
(HAPI) was performed from 1980-2015. Search terms used included: Evidence-based practice, nursing, assessment, evaluation, instruments, and tool (see Figure 1). In addition a manual search of the reference lists of retrieved articles was also performed to identify potentially missed articles in the electronic search. Articles selected for full review included those reporting on instruments used for measuring nurse's knowledge, belief, value, understanding, attitude and im- plementation of evidence-based practice. Seventeen tools were identified and reviewed for potential use. After careful review and discussion with the EBP subcommittee of our Nursing Research Council (NRC) a decision was made that none of the existing tools met the criteria for assessing value, knowledge and implementation of EBP in one concise tool. A decision was made to develop and validate a new tool.

Table 1. EBP assessment tools evaluated

\begin{tabular}{|c|c|c|}
\hline Author, date & What the tool assessed & Reason for not selecting \\
\hline Bonner \& Sando 2008 & $\begin{array}{l}\text { Edmonton Research Orientation Survey (EROS) } \\
\text { To determine nurses, attitude, knowledge and use of } \\
\text { research }\end{array}$ & $\begin{array}{l}\text { Survey was focused more on research than } \\
\text { EBP }\end{array}$ \\
\hline Eller et al. 2003 & Knowledge, Attitudes and Practices (KAP) survey & Assessed Research Knowledge not EBP \\
\hline Estabrooks et al. 2007 & $\begin{array}{l}\text { Survey Questionnaire of } \\
\text { Practice and Source of Knowledge }\end{array}$ & Did not assess value and implementation \\
\hline Funk et al. 1991 & $\begin{array}{l}\text { BARRIERS Scale The Barriers to Research Utilization } \\
\text { Scale, developed in } 1987\end{array}$ & Only assessed barriers \\
\hline Gerrish et al. 2007 & $\begin{array}{l}\text { Developing Evidence-Based Practice (DEBP) } \\
\text { questionnaire } 49 \text { items }\end{array}$ & Did not assess implementation \\
\hline McColl et al. 1998 & Attitudes toward evidence based medicine & Did not assess value or implementation \\
\hline Melnyk et al. 2008 & $\begin{array}{l}16 \text { item believe scale } \\
18 \text { item implementation }\end{array}$ & $\begin{array}{l}\text { Considered. Did not have a separate } \\
\text { knowledge domain. Did have knowledge } \\
\text { questions as part of the implementation } \\
\text { domain }\end{array}$ \\
\hline Munroe et al. 2008 & Knowledge Skills and Attitudes about EBP & Lengthy survey \\
\hline Nagy et al. 2001 & Assessed Nurses believes of EBP & $\begin{array}{l}\text { Did not address value, knowledge and } \\
\text { implementation }\end{array}$ \\
\hline O’Donnell 2004 & $\begin{array}{l}\text { Aim was to assess EBP knowledge for primary care } \\
\text { practitioners }\end{array}$ & Geared towards primary care practitioners \\
\hline Pravikoff et al. 2005 & $\begin{array}{l}\text { Information Literacy for Evidence Based Nursing } \\
\text { Practice } \\
\text { Readiness for nurses using EBP }\end{array}$ & Did not assess value \\
\hline Pryse et al. 2014 & $\begin{array}{l}\text { EBP Nursing Leadership Scale (10 items) } \\
\text { EBP Work Environment Scale (8 items) }\end{array}$ & $\begin{array}{l}\text { Did not assess staff nurses Value, } \\
\text { Implementation, Knowledge of EBP }\end{array}$ \\
\hline Rolf et al. 2008 & $\begin{array}{l}\text { Self-developed survey } \\
\text { Survey to explore nurses understanding and } \\
\text { interpretation of EBP }\end{array}$ & Did not assess implementation \\
\hline $\begin{array}{l}\text { Ruzafa-Martinez et al. } \\
2013\end{array}$ & $\begin{array}{l}\text { Evidence-Based Practice Evaluation Competencies } \\
\text { Questionnaire (EBP-COQ) }\end{array}$ & $\begin{array}{l}\text { Did not assess staff nurses Value, } \\
\text { Implementation, Knowledge of EBP }\end{array}$ \\
\hline Sherriff et al. 2007 & Nurse perception of EBP & $\begin{array}{l}\text { Felt some questions where not applicable to } \\
\text { our practice }\end{array}$ \\
\hline $\begin{array}{l}\text { Steler \& Caramanica } \\
2007\end{array}$ & This tool assessed the process of a EBP education & Did not address value and implementation \\
\hline Upton 1999 & Perception of nurses attitude and knowledge skills & \\
\hline Varnell et al. 2008 & Attitude about EBP & $\begin{array}{l}\text { Did not address knowledge or } \\
\text { implementation }\end{array}$ \\
\hline Waters et al. 2009 & $\begin{array}{l}\text { Assess attitude and knowledge about EBP } \\
\text { Nurses Perception }\end{array}$ & Adapted from another survey \\
\hline
\end{tabular}




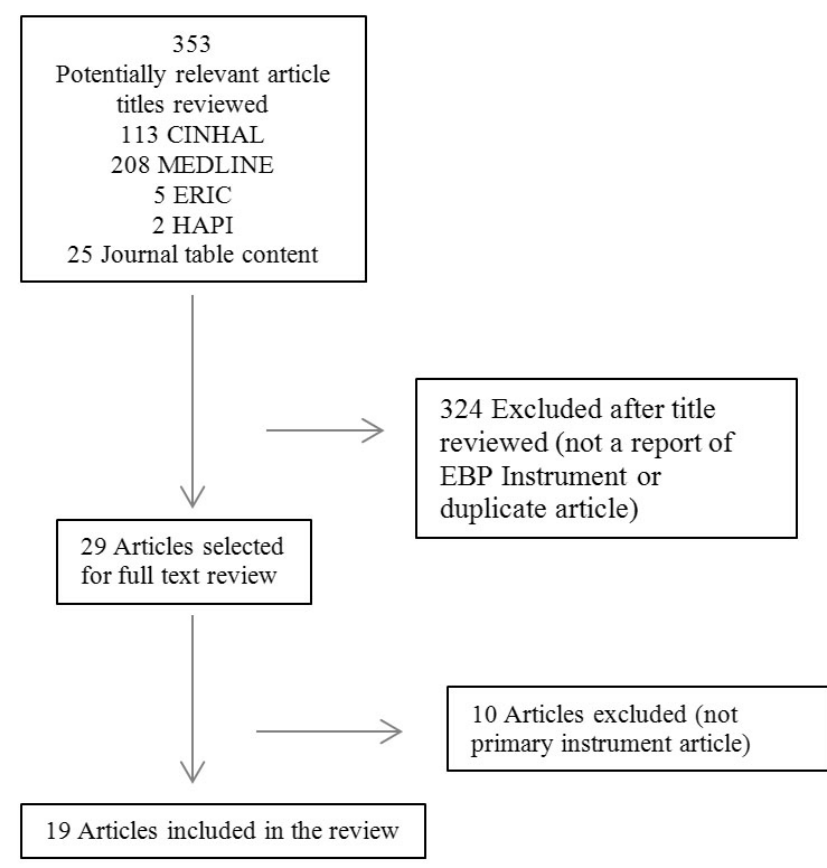

Figure 1. Search for and selection of articles for review

The theoretical domains identified in the articles reviewed included beliefs, barriers, value, readiness to change, knowledge and implementation. For our purposes the concepts of value, knowledge, and implementation were most relevant.

For our purpose, value is defined as how important nurses believe EBP is in their own practice. Value is a critical domain because if nurses do not believe care based on evidence results in improved patient outcomes, they will not value the process. Bandura's SCT advises that in order for learning to be successful, the student must be motivated to imitate the modeled behavior. ${ }^{[14]}$ Information alone does not result in behavior change. Wells, Free, and Adams, reported negative beliefs, attitudes, and values have been shown to be powerful barriers to EBP. ${ }^{[32]}$

Knowledge is defined as having an understanding of how to perform the steps of EBP. Knowledge is essential in order to properly translate and implement evidence into practice. Kim et al. evaluated the impact of a nine month EBP fellowship program for nurses, revealing an increase in implementation with an increase in knowledge and skills in EBP. ${ }^{[33]}$ Actual knowledge can be hard to measure in a brief survey instrument; therefore, we have defined the domain of knowledge as the individual's perceived knowledge of EBP.

The authors defined implementation as the act of carrying out the steps of the EBP process. It is widely recognized that EBP is a critical step in improving the quality and safety of healthcare. The Institute of Medicine (IOM) has established a projected goal that by the year $2020,90 \%$ of all clinical decisions will be supported by the best available evidence. ${ }^{[34]}$

SCT theoretical framework guided our decision for the distinction of knowledge and implementation as separate domains. SCT assumes that learning can be achieved without the implementation of acquired knowledge.

These major concepts of value, knowledge and implementation became the domains for the new instrument. Two of the study authors then began to develop items relevant to each topic domain. The authors created the items from a review of existing tools and literature on EBP. Throughout the review, the authors collected information which pertained to the three chosen theoretical domains. The information was assembled and used to guide the authors with the formulation of items. Fifty-eight items were initially composed, and after careful revision a total of 34 items remained falling within the three domains. Most questions provided a five point Likert-type scale for the response. Initial testing focused on evaluating each item separately within each domain.

\section{Phase II-Internal}

Preliminary validity testing was conducted using staff from the study hospital. Three separate groups worked sequentially to improve and refine the items prior to a more rigorous content validity testing using content experts throughout the country (see Table 2). Figure 2 demonstrates both the internal and external review and tool revision.

Group one included staff with expertise in EBP $(n=10)$. This group reviewed the initial measure, and were asked the following questions regarding each item: 1) the question is clear as written; 2) the question is relevant to the topic of EBP; 3) do you agree with the placement of the question in the current domain; 4) do you have any additional feedback regarding the question or the survey as a whole? Discussions with this sample of nurses led to the elimination of 6 questions, and the revision of 7 questions. The instrument now contained 28 items.

Group two consisted of a panel of experts $(\mathrm{n}=8)$, including an expert on survey design, a nurse scientist, and several nurses who have had advanced training in EBP. In an effort to determine that our instrument was measuring what we intended it to, the developers held a cognitive interview session with each of these experts. During these cognitive interview sessions the experts read each item and explained what they understood the question to be asking. Based on this process 2 of the questions were removed from the instrument, 26 questions remained.

Group three included cognitive interviews with staff nurses $(n=6)$ from our institution with varying levels of education 
and years of nursing experience. Each nurse met with one of the developers, read individual items and explained what they understood the question to be asking. These nurses were then asked to provide an answer for each item in the instrument. Finally, they described the steps they took to arrive

Internal Experts

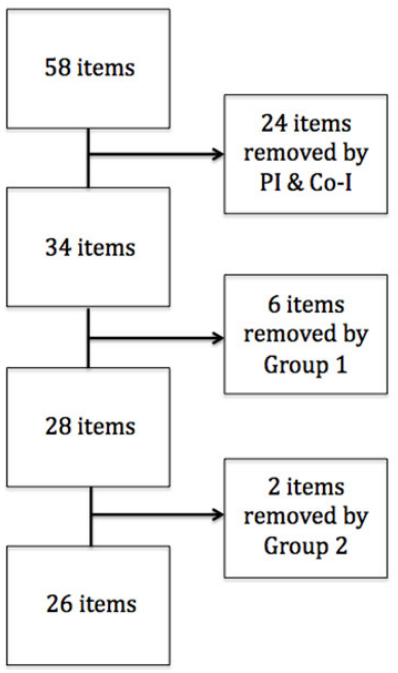

Figure 2. Item refinement

Table 2. Demographics of nursed included in face validity testing $\mathrm{n}=6$ nurses

\begin{tabular}{ll}
\hline Items & \\
\hline Age & Range $36-52$ yrs \\
Experience & Range 2.8-30 yrs \\
Education & \\
AD & $\mathrm{n}=1$ \\
BSN & $\mathrm{n}=3$ \\
BSN, MPH & $\mathrm{n}=1$ \\
MSN & $\mathrm{n}=1$ \\
\hline
\end{tabular}

\section{Phase III-Content validity index-external}

Content validity indices (CVI) are widely used to assess content validity in nursing research. ${ }^{[35]}$ The process of establishing a CVI includes several steps, from engaging a panel of experts to rounds of feedback on relevance and clarity of individual items. This work follows the previously established methodology. ${ }^{[16,35-37]}$ The first step was to identify EBP experts with background in either academic and/or clinical practice settings throughout the United States and invite them to form an expert panel $(n=15)$. Once they agreed to be part of the panel each expert received a link to a web-based survey, which was their means to review our EBP tool and its individual items. A reminder email was sent two weeks after the original request.

The items appeared in a random order on the survey. Experts 122 at each answer. All of the nurses in this sample understood every question as intended by the authors. They were also able to respond to each item and provide logical step-by-step reasoning as to how they arrived at their answers.

External Experts

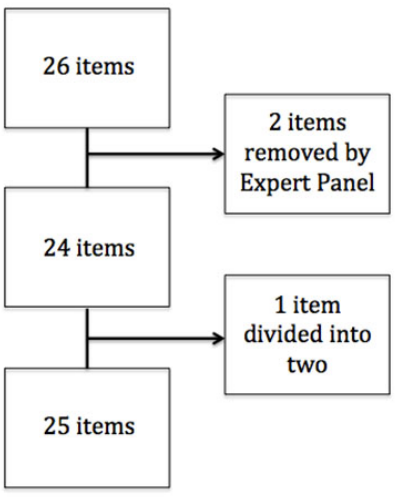

rated each item for both relevance to the topic (1-completely irrelevant, 2-minimally relevant, 3-very relevant, 4-extremely relevant) and clarity (1-very unclear needs to be completely revised, 2-fairly unclear and needs to be revised quite a bit, 3 -fairly clear needs to be only minimally revised, 4-very clear no revisions are needed). The experts were also provided with the theoretical domains value, implementation and knowledge, and were asked to choose the most appropriate domain for each item. Items that were rated 3 or 4 on both relevance and clarity by a minimum of $80 \%$ of the experts were included in our final survey instrument.

\section{Results}

Ten of the 15 experts completed the survey, yielding a $67 \%$ response rate. Demographic information for the EBP experts is included in Table 3. The instrument initially reviewed by the external content experts contained 26 items. Items not rated relevant by at least $80 \%$ of these experts were removed $(x=2)$. Items rated relevant, but noted to be unclear or in need of improvement were reworded and resent to the ten experts $(x=7)$. A reminder was again sent two weeks after the initial request. Six experts responded to the second clarity survey. At this point the remaining items were determined to be relevant and clear; the developers addressed all comments from the experts. 
Table 3. Demographic information: external panel EBP experts

\begin{tabular}{lllllll}
\hline Practice Location & & Practice Setting & & Highest Nursing Degree & Years of RN Experience \\
\hline Arkansas & 1 & Teaching Hospital & 3 & MS & 4 & Range: 14-43 years \\
Canada, BC & 1 & Community Hospital & 1 & PhD & 4 & \\
Massachusetts & 2 & College/University & 3 & DNP & 1 & \\
New York & 1 & Academic/Community & 1 & & \\
Ohio & 2 & Federal Ambulatory & 1 & & \\
Texas & 1 & & & & \\
Washington & 1 & & & & \\
\hline
\end{tabular}

Note. 9 experts provided demographic data.

Item-level content validity index (I-CVI) was calculated for both the relevance and clarity results (see Table 4). I-CVI refers to the proportion of experts that provided a rating of 3 (very relevant) or 4 (extremely relevant) on the relevance scale and a rating of 3 (fairly clear needs to be only minimally revised) or a 4 (very clear no revisions are needed) on the clarity scale. ${ }^{[37]}$ The I-CVI cutoff should be based on the number of experts surveyed and both Lynn and Polit et al. recommend $>.78$ when 6-10 experts are being used. ${ }^{[35,36]}$ We chose a conservative I-CVI of $\geq .80$ for both relevance and clarity.

Table 4. Item-level content validity index

\begin{tabular}{|c|c|c|c|c|}
\hline \multirow[b]{2}{*}{ Abbreviated Sample Item } & \multicolumn{3}{|l|}{ I-CVI } & \multirow[b]{2}{*}{ Rationale } \\
\hline & Relevance & Clarity & $\begin{array}{l}\text { Clarity } \\
\text { Revised Items }\end{array}$ & \\
\hline \multicolumn{5}{|l|}{ Retained Items } \\
\hline $\begin{array}{l}\text { Environment that values } \\
\text { change based in evidence }\end{array}$ & 1.0 & 1.0 & N/A & $\begin{array}{l}\text { Met the predetermined standard of } \geq .8 \text { for both clarity } \\
\text { and relevance with no suggestions for revisions from } \\
\text { experts. Question accepted with no changes. }\end{array}$ \\
\hline $\begin{array}{l}\text { EBP not important to my } \\
\text { practice }\end{array}$ & 1.0 & 1.0 & N/A & $\begin{array}{l}\text { Met the predetermined standard of } \geq .8 \text { for both clarity } \\
\text { and relevance with no suggestions for revisions from } \\
\text { experts. Question accepted with no changes. }\end{array}$ \\
\hline \multicolumn{5}{|l|}{ Revised Items } \\
\hline $\begin{array}{l}\text { Knowledgeable with a ranking } \\
\text { system for the hierarchy of } \\
\text { evidence }\end{array}$ & 1.0 & .78 & 1.0 & $\begin{array}{l}\text { Original I-CVI for clarity below the predetermined } \\
\text { standard of } \geq .8 \text {. Question revised for clarity. }\end{array}$ \\
\hline $\begin{array}{l}\text { In the past } 12 \text { months how } \\
\text { often have your results from } \\
\text { EBP resulted in a change in } \\
\text { clinical practice }\end{array}$ & 1.0 & .78 & 1.0 & $\begin{array}{l}\text { Original I-CVI for clarity below the predetermined } \\
\text { standard of } \geq .8 \text {. Question revised for clarity. }\end{array}$ \\
\hline \multicolumn{5}{|l|}{ Reworded Items } \\
\hline $\begin{array}{l}\text { Utilizing EBP, I am able to } \\
\text { change agency-wide nursing } \\
\text { practice }\end{array}$ & .89 & .89 & 1.0 & $\begin{array}{l}\text { Question reworded to strengthen item based on } \\
\text { recommendations from content experts. }\end{array}$ \\
\hline Knowledgeable with EBP & 1.0 & .89 & 1.0 & $\begin{array}{l}\text { Question reworded to strengthen item based on } \\
\text { recommendations from content experts. }\end{array}$ \\
\hline \multicolumn{5}{|l|}{ Excluded Items } \\
\hline $\begin{array}{l}\text { No time to conduct an EBP } \\
\text { review in my practice }\end{array}$ & .78 & .67 & N/A & Relevancy $\mathrm{I}-\mathrm{CVI} \leq .8$, question eliminated. \\
\hline $\begin{array}{l}\text { How did you share } \\
\text { information }\end{array}$ & .78 & .78 & N/A & Relevancy I-CVI $\leq .8$, question eliminated. \\
\hline
\end{tabular}


Based on the results of the initial response from external content experts, two of the questions were removed from the instrument because they did not meet the I-CVI cutoff of .80 for relevance to topic. The experts were able to correctly identify the domain placement for all questions. Seven items received an I-CVI of $<.80$ on the clarity scale. These seven items included the two that were removed based on relevance ratings, leaving five items to be revised for clarity. The results also included comments concerning minor wording revisions for twelve items that were already rated as clear by at least $80 \%$ of the experts, and a suggestion to divide one of the items into two separate questions. The authors considered all of the comments; revisions were incorporated when they improved the quality of the survey items. For example, changing the words "allow" to "enable" and "Interpreting" to "critically appraising" clarified the intended questions. A total of 18 items were reworded or revised for clarity, and included in the second round of survey to the external content experts. The items in this follow up survey were not randomized, and were placed under their appropriate domain/section heading of value, knowledge or implementation. Six of the ten experts responded to the second survey. All 18 items in the follow-up survey items were found to be clear by the respondents with an I-CVI of $>.80$.

\section{Discussion}

The use of EBP is widely accepted as the best approach to maintaining quality patient care. Nevertheless, it is apparent there are barriers to nurses incorporating EBP into their everyday clinical practice. ${ }^{[38-41]}$ In part, this is attributed to a lack of knowledge. As a result, academic institutions and hospitals are focusing on continuing EBP education. Successful educational initiatives need to be tailored to meet the needs of the learners. To help assess this need we developed the Quick-EBP-VIK that measures three domains of EBP, value (V), implementation (I), and knowledge (K). The Quick-EBP-VIK is a measure that may provide insight to nursing educators, and guide future nursing curricula. One of the challenges hospitals encounter in offering EBP education is that nurses have varying levels of education and clinical experience. Implementing the Quick-EBP-VIK may enable hospital educators to develop effective strategies to maximize continuing education initiatives focused on EBP. For example educators could group nurses into levels according to their knowledge scores. This would support tailored educational programs aimed at specific learning needs of nursing staff. The Quick-EBP-VIK may also be administered pre and post EBP coursework to evaluate the effectiveness of educational efforts. With further testing we hope the Quick-EBP-VIK could be used longitudinally as an ongoing assessment of EBP culture as reflected by value, implementation and knowledge in an organization.

Our instrument was developed with a conscientious use of published survey development methods. First, by using existing literature and qualitative interviews we were able to identify subject domains and items that the authors believe to be essential to the topic of EBP. The use of CVI as described by Lynn $^{[36]}$ was then performed for both the relevance and clarity of each question. It is recommended that a minimum of three experts evaluate questions for content validation. ${ }^{[35,36]}$ We received ten responses from the experts who were initially asked to review the survey. Six of the experts who responded to our initial request reviewed the items that were reworded or revised for clarity. For this content validity method six experts is considered more than sufficient. By asking the reviewer to rate each question with separate scales for clarity and relevance we were able to obtain specific information that assisted in the final question selection. The final product is a 25 -item tool with all questions receiving $\geq .80 \mathrm{I}-\mathrm{CVI}$ for both clarity and relevance.

\section{Limitations}

One limitation is that our instrument measures the perceived knowledge of an individual that may not accurately reflect their actual knowledge. As with all self-report tools, there is the potential that a participant may under or over assess their abilities and knowledge. Four of the experts who participated in our initial round of review did not participate in our second round of review.

\section{Conclusion}

This paper describes the process of developing, refining and content validity testing of the Quick-EBP-VIK. In order to use this tool with confidence additional psychometric testing is necessary, including additional types of validity, such as construct validity, and test-retest reliability. In addition the demonstration of internal consistency and existence of the three subscales is critical, along with generalizability analysis to evaluate the amount of variance explained by items, individuals, and other relevant variables such as nurse's education level The Quick-EBP-VIK has the potential to be a valuable tool in assessing nurse's value, knowledge, and implementation of EBP, and helping to guide future nursing curricula.

\section{Conflicts of Interest Disclosure}

The authors declare that there is no conflict of interest. 


\section{REFERENCES}

[1] Grimshaw J, Martin EM, Thomas R, et al. Toward Evidence-Based Quality Improvement Evidence (and its Limitations) of the Effectiveness of Guideline Dissemination and Implementation Strategies 1966-1998. Journal of General Internal Medicine. 2006; 21(S2): S14S20. PMid:16637955

[2] Melnyk B, Fineout-Overholt E. Evidence-Based Practice in Nursing and Health Care a Guide to Best Practice. Philadelphia: Lippincott, Williams \& Wilkins. 2015.

[3] Stetler CB. Updating the Stetler Model of Research Utilization to Facilitate Evidence-Based Practice. Nursing Outlook. 2001; 49(6): 272-279. PMid:11753294 http://dx.doi.org/10.1067/mno.2 001.120517

[4] Melnyk B, Fineout-Overholt E, Feinstein N, et al. Nurses' perceived knowledge, beliefs, skills, and needs regarding evidence-based practice: implications for accelerating the paradigm shift. Worldviews on Evidence-Based Nursing. 2004; 1(3): 185-193. PMid:17163896 http://dx.doi.org/10.1111/j.1524-475X.2004.04024.x

[5] Melnyk B, Fineout-Overholt E, Mays M. The Evidence-Based Practice Beliefs and Implementation Scales: psychometric properties of two new instruments. Worldviews on Evidence-Based Nursing. 2008; 5(4): 208-216. PMid:19076922 http://dx.doi.org/10.1111/j $.1741-6787.2008 .00126 . \mathrm{x}$

[6] Schulman C. Strategies for starting a successful evidence-based practice program. AACN Advanced Critical Care. 2008; 19(3): 301311. PMid:18670205 http://dx.doi .org/10.1097/01 . AACN . 0 $000330381.41766 .2 \mathrm{a}$

[7] Eller L, Kleber E, Wang S. Research knowledge, attitudes and practices of health professionals. Nursing Outlook. 2003; 51(4): 165-170. http://dx.doi.org/10.1016/S0029-6554(03)00112-X

[8] Thiel L, Ghosh Y. Determining registered nurses' readiness for evidence-based practice. Worldviews on Evidence-Based Nursing/Sigma Theta Tau International, Honor Society of Nursing. 2008; 5(4): 182-192. PMid:19076919 http://dx.doi.org/10.1111/j .1741-6787.2008.00137.x

[9] Pravikoff D, Tanner A, Pierce S. Readiness of U.S. nurses for evidence-based practice. The American Journal of Nursing. 2005; 105(9): 40-51. PMid:16138038 http://dx.doi .org/10.1097/0 0000446-200509000-00025

[10] Bandura A. Social foundations of thought and action: A social cognitive theory. Englewood Cliffs, NJ: Prentice-Hall. 1986.

[11] Pajares F. Overview of social cognitive theory and of self-efficacy [Internet]. 2002. Available from: http://www . emory. edu/EDUC ATION/mfp/eff.html

[12] Bandura A, Ross D, Ross SA. Imitation of film-mediated aggressive models. Journal of Abnormal and Social Psychology. 1963; 66(1): 3-11. http://dx.doi.org/10.1037/h0048687

[13] Schunk DH. Learning theories: an educational perspective. Upper Saddle River, NJ: Pearson. 2004.

[14] Bandura A. Social cognitive theory: an agentic perspective. Annual Review of Psychology. 2001; 52: 1-26. PMid:11148297 http: //dx.doi.org/10.1146/annurev.psych.52.1.1

[15] Zomorodi M, Lynn MR. Instrument Development Measuring Critical Care Nurses' Attitudes and Behaviors with End-of life Care. Nursing Research. 2010; 59(4): 234-240. PMid:20467339 http: //dx.doi.org/10.1097/NNR.0b013e3181dd25ef

[16] Bonner A, Sando J. Examining the knowledge, attitude and use of research by nurses. Journal of Nursing Management. 2008; 16(3): 334-343. PMid:18324993 http://dx.doi.org/10.1111/j.136 5-2834.2007.00808.x

Published by Sciedu Press
[17] Estabrooks CA. Translating research into practice: Implications for organizations and administrators. Canadian Journal of Nursing Research. 2003; 4(1): 39-45.

[18] Funk SG, Champagne MT, Wiese RA, et al. BARRIERS: The barriers to research utilization scale. Applied Nursing Research. 1991; 4: 3945. http://dx.doi.org/10.1016/S0897-1897 (05) 80052-7

[19] Gerrish K, Ashworth P, Lacey A, et al. Factors influencing the development of evidence-based practice: a research tool. Journal of Advanced Nursing. 2007; 57(3): 328-338. PMid:17233652 http://dx.doi.org/10.1111/j.1365-2648.2006.04112.x

[20] McColl A, Smith H, White P, et al. General practitioner's perceptions of the route to evidence based medicine: a questionnaire survey. BMJ. 1998; 316(7128): 361-365. PMid:9487174 http: $/ / \mathrm{dx}$.doi.org/10.1136/bmj.316.7128.361

[21] Munroe D, Duffy P, Fisher C. Nurses Knowledge, skills and attitude related to evidence-based practice: before and after organizational support. Medsurg Nursing. 2008; 17(1): 55-60. PMid:18429543

[22] Nagy S, Lumby J, McKinley S, et al. Nurses' beliefs about the conditions that hinder or support evidence-based nursing. International Journal of Nursing Practice. 2001; 7: 314-321. http: //dx.doi.org/10.1046/j.1440-172X.2001.00284.x

[23] O'Donnell CA. Attitudes and knowledge of primary care professionals towards evidence-based practice: a postal survey. Journal of Evaluation in Clinical Practice. 2004; 10(2): 197-205. PMid:15189386 http://dx.doi.org/10.1111/j.1365-2753.2003.00458.x

[24] Pryse Y, McDaniel A, Schafer J. Psychometric Analysis of Two New Scales: The Evidence-Based Practice Nursing Leadership and Work Environment Scales. Worldviews on Evidence-Based Nursing. 2014; 11(4): 240-247. PMid:24986757 http://dx.doi.org/10.1111 /wvn. 12045

[25] Rolfe G, Segrott J, Jordan S. Tensions and contradictions in nurses' perspectives of evidence-based practice. Journal of Nursing Management. 2008; 16 (4): 440-451. PMid:18405261 http://dx.doi.o $\mathrm{rg} / 10.1111 / \mathrm{j} .1365-2834.2008 .00864 . \mathrm{x}$

[26] Ruzafa-Martinez M, Lopez-Iborra L, Moreno-Casbas T, et al. Development and validation of the competence in evidence based practice questionnaire (EBP-COQ) among nursing students. BMC Medical Education. 2013; 13(19). http://dx.doi .org/10.1186/1472-6 920-13-19

[27] Sherriff K, Wallis M, Chaboyer W. Nurses' attitudes to and perceptions of knowledge and skills regarding evidence-based practice. International Journal of Nursing Practice. 2007; 13(6): 363369. PMid:18021165 http://dx.doi.org/10.1111/j.1440-1 $72 \mathrm{X} .2007 .00651 . \mathrm{x}$

[28] Stetler C, Caramanica L. Evaluation of an evidence-based practice initiative: outcomes, strengths and limitations of a retrospective, conceptually-based approach. Worldviews on Evidence-Based Nursing/Sigma Theta Tau International, Honor Society of Nursing. 2007; 4(4): 187-199. PMid:18076462 http://dx.doi.org/10.1111/j $.1741-6787.2007 .00097 . x$

[29] Upton D. Attitudes towards, and knowledge of, clinical effectiveness in nurses, midwives, practice nurses and health visitors. Journal of Advanced Nursing. 1999; 29(4): 885-893. http://dx.doi.org/1 $0.1046 / j .1365-2648.1999 .00967 . x$

[30] Varnell G, Haas B, Duke G, et al. Effect of an educational intervention on attitudes toward and implementation of evidencebased practice. Worldviews on Evidence-Based Nursing/Sigma Theta Tau International, Honor Society of Nursing. 2008; 5(4): 172181. PMid:19076918 http://dx.doi.org/10.1111/j.1741-6 787.2008.00124.x

[31] Waters D, Crisp J, Rychetnik L, et al. The Australian experience of nurses' preparedness for evidence-based practice. Journal 
of Nursing Management. 2009; 17(4), 510-518. PMid:19531151 http://dx.doi.org/10.1111/j.1365-2834.2009.00997.x

[32] Wells N, Free M, Adams R. Nursing research internship enhancing evidence-based practice among staff nurses. Journal of Nursing Administrator. 2007; 37(3): 135-143. PMid:17496778 http: //dx.doi.org/10.1097/01. NNA.0000262732.14123.a2

[33] Kim SC, Brown CE, Ecoff L, et al. Regional evidence-based practice fellowship program: impact on evidence-based practice implementation and barriers. Clinical Nursing Research. 2013; 22(1): 5169. PMid:22645401 http://dx.doi .org/10.1177/105477381 2446063

[34] Institute of Medicine. The future of nursing: Leading change, advancing health [Internet]. 2010. Available from: http://books.na p.edu/openbook.php?record_id=12956\&page=R1

[35] Polit DF, Beck CT, Owen SV. Is the CVI an acceptable indicator of content validity? Appraisal and recommendations. Research in Nursing \& Health. 2007; 30(4): 459-467. PMid:17654487 http: //dx.doi.org/10.1002/nur. 20199

[36] Lynn MR. Determination and quantification of content validity. Nursing Research. 1986; 35(6): 382-385. PMid:3640358 http: //dx.doi.org/10.1097/00006199-198611000-00017

[37] Schilling LS, Dixon J, Knafl KA, et al. Determining content validity of a self-reported instrument for adolescents using a heterogeneous expert panel. Nursing Research. 2007; 56(5): 361366. PMid:17846558 http://dx.doi.org/10.1097/01. NNR . 00 00289505.30037 .91

[38] Chan GK, Barnason S, Dakin CL, et al. Barriers and perceived needs for understanding and using research among emergency nurses. Journal of Emergency Nursing. 2010; 37(1): 24-31. PMid:21237364 http://dx.doi.org/10.1016/j.jen.2009.11.016

[39] Karkos B, Peters K. A magnet community hospital: fewer barriers to nursing research utilization. Journal of Nursing Administration. 2006; 36(7-8): 377-382. PMid:16902362 http://dx .doi.org/1 $0.1097 / 00005110-200607000-00011$

[40] Sommer SK. An investigation of the barriers and facilitators of research utilization among a sample of registered nurses. Dissertation Abstracts International. 2003; 64: 2780A.

[41] Vanhook PM. Overcoming the barriers to EBP. Nursing Management. 2009; 40(8): 9-11. PMid:19667911 http://dx.doi.org/10.10 97/01. NUMA.0000359200.14210. af 